\title{
Dampak Aplikasi ScratchJr terhadap Ketrampilan Problem-Solving Anak Usia Dini
}

\author{
Novita Eka Nurjanah ${ }^{\circledR}$, Ruli Hafidah ${ }^{1}$, Muhammad Munif Syamsuddin' ${ }^{1}$, Adriani Rahma \\ Pudyaningtyas ${ }^{1}$, Nurul Kusuma Dewi ${ }^{1}$, Vera Sholeha ${ }^{1}$ \\ Pendidikan Guru Pendidikan Anak Usia Dini, Universitas Sebelas Maret, Indonesia(1) \\ DOI: $10.31004 /$ obsesi.v6i3.1531
}

\begin{abstract}
Abstrak
Konsep budaya digital mengungkapkan bahwa buta aksara tidak lagi diartikan sebagai keadaan tidak mengetahui cara membaca dan menulis. Buta aksara di era digital diartikan sebagai keadaan tidak dapat menggunakan komputer dan teknologi. Oleh karena itu, pembelajaran berbasis teknologi digital harus dimulai sejak anak usia dini. Tujuan penulisan artikel ini adalah untuk mendeskripsikan dampak pembelajaran berbasis aplikasi scratchJr terhadap ketrampilan problem-solving anak usia ini 5-7 tahun. Metode yang digunakan dalam penulisan artikel ini adalah systematic literatur review dengan melakukan analisis 15 artikel jurnal internasional. Hasil analisis studi teoritis menunjukkan bahwa pemrograman komputer melalui aplikasi scratchJr memungkinkan anak usia dini untuk terlibat dalam pembuatan cerita interaktif, permainan, serta kesenangan digital secara mandiri, serta memfasilitasi ketrampilan problem-solving yang kreatif, penalaran logis, dan mendukung kolaborasi. Anak usia dini dengan cepat dapat mengakses serta memahami kemampuan pemrograman komputer dengan menggunakan pemikiran matematis dalam pendekatan untuk pemecahan masalah (problem-solving).
\end{abstract}

Kata Kunci: scratchJr; problem-solving; anak usia dini

\begin{abstract}
The concept of digital culture reveals that illiteracy is no longer defined as a state of not knowing how to read and write. Illiteracy in the digital era is defined as a state of being unable to use computers and technology. Therefore, digital technology-based learning must start from an early age. The purpose of this article is to describe the impact of ScratchJr application-based learning on the problem-solving skills of children aged 5-7 years. The method used in writing this article is a systematic literature review by analyzing 15 international journal articles. The results of the analysis of theoretical studies show that computer programming through the scratchJr application allows early childhood to be involved in creating interactive stories, games, and digital fun independently, and facilitates creative problem-solving skills, logical reasoning, and supports collaboration. Early childhood can quickly access and understand computer programming skills by using mathematical thinking in a problem-solving approach.
\end{abstract}

Keywords: scratcJr; problem-solving; early chilhood

Copyright (c) 2021 Novita Eka Nurjanah, et. all.

$\triangle$ Corresponding author:

Email Address : novitapgpaud@staff.uns.ac.id (Surakarta, Jawa Tengah)

Received 7 February 2021, Accepted 8 July 2021, Published 26 November 2021 


\section{PENDAHULUAN}

Ketrampilan pemecahan masalah atau problem-solving skills diakui sebagai komponen penting untuk setiap anak usia dini dalam menentukan nasibnya di masa depan yang akan datang. Hal tersebut selaras dengan apa yang dijelaskan oleh pakar peneliti (Joseph \& Strain, 2010) yang menyatakan bahwa ketrampilan pemecahan masalah atau problem-solving skills pada anak usia dini merupakan kunci keutamaan dalam pengembangan kompetensi sosial. Pada tahun 2012, National Research Council (AS) mendefinisikan keterampilan abad ke-21 sebagai dasar proses pembelajaran. Keterampilan ini dibagi menjadi tiga domain kompetensi, antara lain : (1) interpersonal; (2) intrapersonal; (3) kognitif. Domain kognitif meliputi berpikir kritis, kreativitas, fungsi eksekutif, dan ketrampilan pemecahan masalah atau problem-solving skills (Araiza-Alba et al., 2021).

Pemecahan masalah (problem-solving) adalah dasar keterampilan fungsi eksekutif, dan itu didefinisikan sebagai proses yang membutuhkan kemampuan untuk mendefinisikan serta mengidentifikasi masalah, mencari solusi alternatif, serta menerapkan solusi terbaik dalam situasi yang relatif baru (Yu et al., 2015). Pemecahan masalah (problem-solving) pada anak usia dini melibatkan proses berpikir mengenai suatu pemecahan masalah yang efektif serta efisien sehingga anak harus melaksanakan evaluasi terhadap perbedaan informasi untuk menentukan bukti dari informasi yang telah dimiliki (Busch \& Legare, 2019). Pengembangan ketrampilan problem-solving ini harus dipupuk serta ditanamkan pada tahun-tahun awal melalui penggunaan aktivitas atau kegiatan langsung dan tertanam sesuai dengan usia serta tahap perkembangan anak usia dini.

Menurut Center on the Developing Child Havard University, kemampuan fungsi eksekutif adalah sekumpulan keterampilan kognitif yang memungkinkan anak untuk berpikir kritis, membuat rencana, fokus, mengingat perintah, serta mengerjakan beberapa hal dalam satu waktu sekaligus. Oleh karena itu, ketrampilan problem-solving anak merupakan sesuatu hal yang penting karena sebagai dasar dari keterampilan kognitif. Namun, fenomena yang ada saat ini ketrampilan problem-solving jarang sekali disentuh oleh guru pada lembaga pendidikan anak usia dini terutama ketika pembelajaran yang dilaksanakan melalui pembelajaran online atau e-learning pada waktu masa pandemi covid-19 seperti zaman sekarang ini.

Banyak guru pendidikan anak usia dini belum memberikan kegiatan pembelajaran yang memadai dalam bidang ketrampilan pemecahan masalah atau problem-solving (Lile Diamond, 2018). Terlebih pada masa pandemi covid-19, guru PAUD dituntut untuk dapat tetap memberikan fasilitas kegiatan pembelajaran anak melalui e-learning. Pada zaman sekarang ini stimulasi ketrampilan problem-solving anak usia dini tidak optimal, hal ini karena saat pembelajaran online (e-learning) yang dilakukan melalui zoom, google meet, serta whatsapp grup pada waktu pandemi covid-19, guru PAUD tidak memberikan aktivitas atau kegiatan yang menstimulasi ketrampilan problem-solving anak usia dini. Ketrampilan problemsolving ini berkaitan dengan (1) kemampuan untuk mengenali tugas, aktivitas atau kegiatan, serta masalah; (2) menghasilkan serta menerapkan solusi yang paling sesuai untuk berbagai macam permasalahan yang diidentifikasi; (3) mengevaluasi efektivitas solusi yang teridentifikasi untuk memecahkan berbagai macam permasalahan yang sedang dihadapi (Greenwood et al., 2006). Berdasarkan hasil observasi di lapangan, dalam kegiatan pembelajaran guru hanya menggunakan Lembar Kerja Anak (LKA) dengan metode ceramah atau konvensional.

Melalui metode ceramah atau konvensional, guru pada lembaga pendidikan anak usia dini hanya menjelaskan materi bahan pembejaran yang dibahas sesuai dengan tema pembelajaran yang telah direncanakan sebelumnya, kemudian guru pada lembaga pendidikan anak usia dini meminta anak untuk mengerjakan Lembar Kerja Anak (LKA). Dengan mengerjakan Lembar Kerja Anak (LKA), anak hanya duduk dalam suatu periode waktu tertentu. Hal ini dapat diartikan bahwa anak tidak diajak untuk melakukan aktivitas atau kegiatan yang disesuaikan dengan masa pertumbuhan serta perkembangan anak usia 
dini pada umumnya atau yang semestinya. Dengan kata lain, anak usia dini tidak diberikan pengalaman bervariasi dalam kegiatan pembelajaran, pengalaman dalam bereksplorasi, memecahkan masalah, serta penyelidikan. Sehingga menyebabkan keterampilan yang harus dikuasai anak usia dini pada abad ke-21 ini tidak dapat terstimulasi dengan optimal.

Pada zaman sekarang ini dalam aspek kognitif utamanya ketrampilan problem-solving anak usia dini belum terstimulasi secara optimal. Anak usia dini pada zaman sekarang ini mengalami kesulitan untuk mengidentifikasi berbagai macam permasalahan dalam kehidupan sehari-hari, mencari solusi untuk memecahkan suatu permasalahan dalam kehidupan sehari-hari, serta menerapkan suatu solusi yang sesuai dengan konteks permasalahan yang ada. Hal ini dikarenakan adanya kendala atau permasalahan dalam menerapkan kegiatan pembelajaran yang dapat menstimulasi ketrampilan problem-solving anak ketika belajar dari rumah melalui pembelajaran online atau e-learning pada waktu masa pandemi covid-19.

Pembelajaran online atau e-learning dapat dilaksanakan dengan memanfaatkan teknologi digital. Berdasarkan hasil penelitian, menyatakan bahwa teknologi digital dapat dimanfaatkan sebagai sarana untuk meningkatkan pemikiran kritis, pertanyaan, serta refleksi untuk anak usia dini (Hatzigianni, 2018). Pengembangan media berbasis digital merupakan salah satu usaha yang dapat diterapkan oleh guru di lembaga pendidikan anak usia dini untuk tetap dapat mengembangkan ketrampilan problem-solving pada anak usia dini meskipun melalui pembelajaran secara online (e-learning).

Berdasarkan permasalahan serta persoalan yang sedang dialami oleh guru di lembaga pendidikan anak usia dini pada masa waktu pandemi covid-19 tersebut, salah satu program yang dapat merangsang atau menstimulasi kemampuan pemecahan masalah atau problemsolving anak usia dini di era pada waktu masa pandemi covid-19 seperti zaman sekarang ini adalah pemrograman komputer. Pemrograman komputer yang digunakan adalah scratchJr. Proyek pemrograman komputer scratchJr bertumpu pada suatu pendapat bahwa anak-anak usia dini yang sedang duduk di taman kanak-kanak sampai kelas dua sekolah dasar dapat belajar serta menggunakan atau menerapkan konsep pemrograman komputer serta pemecahan masalah atau problem-solving untuk membuat suatu animasi atau cerita interaktif (Flannery et al., 2013). Dengan program komputer scratchJr ini guru pada lembaga pendidikan anak usia dini dapat mengembangkan berbagai macam kegiatan bermain untuk menstimulasi ketrampilan problem-solving anak.

Tujuan dalam penelitian literatur review ini adalah untuk menjelaskan pemrograman komputer scratchjr dapat membantu memberikan rangsangan atau stimulasi terhadap ketrampilan pemecahan masalah atau problem-solving pada anak usia dini. Novelty pada artikel ini adalah peneliti melakukan analisis narrative synthesis terhadap beberapa artikel mengenai dampak pemrograman komputer scratchjr terhadap ketrampilan problem-solving anak usia dini yang belum pernah dikaji oleh peneliti lain sebelumnya. Jenis penelitian yang digunakan adalah systematic literatur review.

\section{METODOLOGI}

Penelitian ini menggunakan metode systematic literature review. Artikel ini bertujuan dalam melakukan tinjauan literatur mengenai dampak scratchJr terhadap problem-solving anak usia dini 5-7 tahun. Literatur atau sumber pustaka dipilih dari sumber online, termasuk artikel jurnal berjumlah 15. Pencarian dilakukan melalui situs website ERIC, sciencedirect, dan scopus dengan menggunakan kata-kata kunci seperti scratchJr, ketrampilan problem-solving, dan anak usia dini.

Penelitian ini dilakukan dengan beberapa tahapan yaitu mengidentifikasi teori-teori secara sistematis, mengkaji teori-teori dan topik penelitian yang dibahas, menganalisis teoriteori yang berhubungan dengan topik penelitian serta memberikan kesimpulan dari analisis untuk memberikan informasi yang berhubungan dengan topik penelitian. Analisis yang digunakan adalah narrative synthesis. Narrative synthesis adalah pendekatan yang dapat 
dimasukkan ke dalam proses tinjauan sistematis dan sintesis temuan dari berbagai studi yang bergantung pada penggunaan kata-kata dan teks untuk menyajikan temuan dari studi yang dilaporkan (Roberts, Petticrew, Roen, \& Duffy, n.d.,2006).

Tabel 1 Batasan Systematic Literature Review

\begin{tabular}{cc}
\hline Tahun Terbit & 2006-2021 \\
\hline Databases & 1 ERIC, 3 SCOPUS, 11 SCIENCE DIRECT \\
Tipe Dokumen & Artikel \\
Subjek & Anak usia dini \\
Kata-kata Kunci & ScratchJr, problem solving, dan anak usia dini \\
\hline
\end{tabular}

\section{HASIL DAN PEMBAHASAN}

Hasil temuan studi dampak aplikasi scratchjr terhadap ketrampilan problem-solving anak usia dini dapat dilihat pada tabel 2 (lampiran 1)

\section{Ketrampilan Problem-Solving}

Ketrampilan problem-solving adalah salah satu dari beberapa kemampuan yang mulai berkembang pada tahun-tahun awal serta berlanjut selama jangka hidup serta berkontribusi pada pengembangan penentuan nasib dalam diri seorang individu pada masa depan yang akan mendatang (Palmer et al., 2013). Penentuan nasib sendiri tersebut berarti maksudnya didefinisikan sebagai bertindak secara independen, otonom, serta dapat mengatur diri sendiri. Oleh karena itu, sebagai salah satu kemampuan yang lebih lengkap serta kompleks yang dibutuhkan serta dipelajari dalam kehidupan sehari-hari, ketrampilan problem-solving merupakan komponen penting untuk menjalani kehidupan yang ditentukan oleh individu.

Ketrampilan problem-solving mencakup proses perilaku kemampuan kognitif yang diarahkan secara mandiri dimana seorang individu berupaya untuk mengidentifikasi atau menemukan solusi untuk berbagai macam permasalahan yang muncul di sepanjang kehidupan sehari-hari. Secara khusus, proses ini umumnya dikenal sebagai : (1) kemampuan untuk mengenali tugas, aktivitas atau kegiatan, serta masalah; (2) menghasilkan serta menerapkan solusi yang paling sesuai untuk berbagai macam permasalahan yang diidentifikasi; (3) mengevaluasi efektivitas solusi yang teridentifikasi untuk memecahkan berbagai macam permasalahan yang sedang dihadapi (Greenwood et al., 2006). Mendemonstrasikan ketrampilan dalam proses pemecahan masalah atau problem-solving memungkinkan seorang individu untuk berfungsi atau bermanfaat secara mandiri sepanjang aktivitas kehidupan sehari-hari, seperti bersiap-siap di pagi hari, mengerjakan tugas-tugas dari sekolahan, serta terlibat secara sosial bersama dengan orang lain.

Ketrampilan problem-solving anak usia dini berkembang saat mereka terlibat dalam kesempatan belajar yang dirancang untuk membangun kepercayaan diri dalam lingkungan di sekitar. Ketrampilan problem-solving saat ini sangat diperlukan dalam proses penyelesaian permasalahan kehidupan sehari-hari. Menurut Goleman ketrampilan problem-solving anak usia dini merupakan fitur komponen kunci dalam mengembangkan kompetensi sosial sejak usia dini (Joseph \& Strain, 2010). Ketrampilan problem-solving terletak dalam tiga bidang utama : Pertama, ketrampilan problem-solving ini berjalan dengan baik bersama anak usia dini. Anak usia dini dapat menggunakan dalam situasi sosial apa pun untuk menyelesaikan berbagai macam permasalahan dilema sosial. Kedua, ketrampilan problem-solving ini merupakan sarana yang sangat bagus untuk mencegah sejumlah perilaku yang menantang. Ketiga, ketrampilan problem-solving dapat memungkinkan anak usia dini untuk memperbaiki pelanggaran dengan waktu yang cepat dalam hubungan bersama temannya. Kemampuan pemecahan masalah atau problem solving melibatkan proses berpikir mengenai pemecahan masalah yang efektif serta efisien sehingga anak harus melaksanakan evaluasi perbedan informasi untuk menentukan bukti dari informasi yang dimiliki (Busch \& Legare, 2019). 
Ketrampilan problem solving anak usia dini terdiri dari tiga tingkatan yaitu rendah, sedang, dan tinggi (Dyah \& Setiawati, 2019). Keterlibatan guru diperlukan untuk mencapai ketrampilan problem-solving anak yang optimal. Ketrampilan problem-solving dapat diterapkan dalam pembelajaran yang berkaitan dengan kognitif seperti pemecahan masalah konsep bilangan (Setyaningtyas \& Harun, 2020). Selain itu, Ketrampilan problem-solving dapat diterapkan melalui pendekatan saintifik (Nuryatmawati \& Dimyati, 2021).

Dengan demikian, ketrampilan problem-solving ini harus dipupuk serta ditanamkan pada tahun-tahun awal melalui penggunaan aktivitas atau kegiatan langsung yang tertanam sesuai dengan usia serta tahap-tahap perkembangan anak usia dini (Lile Diamond, 2018). Salah satu upaya guru pada lembaga pendidikan anak usia dini untuk membantu memberikan rangsangan atau stimulasi terhadap ketrampilan problem-solving pada anak usia dini adalah dengan memanfaatkan kecanggihan teknologi digital dengan cara menggunakan pemrograman komputer. Salah satu pemrograman komputer yang dapat digunakan adalah scratchjr. Dengan program komputer scratchJr ini guru pada lembaga pendidikan anak usia dini dapat mengembangkan berbagai macam kegiatan bermain untuk menstimulasi ketrampilan problem-solving anak.

\section{Pemrograman Komputer ScratchJr}

ScratchJr merupakan sebuah alat pemrograman grafis yang saat ini dikembangkan untuk anak usia dini yang sedang duduk di taman kanak-kanak sampai anak kelas dua sekolah dasar. ScratchJr dibangun di atas bahasa pemrograman grafis scratch yang menggunakan blok-blok pada layar yang saling berhubungan untuk memprogram animasi karakter. Scratchjr menggunakan bahasa program pengantar yang didesain bagi anak-anak dengan usia lima sampai dengan tujuh tahun untuk membuat animasi cerita interaktif atau permainan dengan menggabungkan blok-blok pemrogrman grafis untuk membuat animasi karakter bergerak, melompat, menari, serta bernyanyi (Bers, 2018b).

ScratchJr memungkinkan anak usia dini untuk menggunakan blok-blok pemrograman yang mengontrol gerakan, penampilan, suara, komunikasi karakter, serta masih banyak fitur komponen yang lainnya. Dengan melalui blok pemrograman ini, anak usia dini dapat belajar konsep dasar serta ide-ide atau gagasan-gagasan hebat dari pengkodean sembari membuat proyek yang bermakna secara individual. Pemrograman komputer dalam scratchJr juga mempunyai beragam jenis kegiatan seperti berlomba, peristiwa matahari terbenam, serta berkendara melintasi tengah kota, dan lain sebagainya. Di sini guru lembaga pendidikan anak usia dini berperan sebagai pembimbing anak usia dini dalam memilih atau menentukan latar belakang, menentukan karakter, serta membuat program untuk mempraktikkan urutan kodekode sederhana yang tersedia (Delacruz, 2020).

ScratchJr sebagai bahasa pemrograman berbasis blok-blok, dapat mendukung anak usia dini untuk mengeksplorasi ide yang kuat dari konsep ilmu komputer antara lain adalah algoritma, debugging, dekomposisi atau modularisasi, struktur kontrol, serta proses desain melalui cara-cara yang menyenangkan serta sesuai dengan tahap-tahap perkembangan anak usia dini. ScratchJr memperkenalkan konsep komputasi seperti pengurutan, loop, peristiwa, dan operator serta melibatkan anak usia dini dalam proses kognitif yang berhubungan dengan pemecahan masalah/ problem solving (Sullivan \& Umashi Bers, 2019). Hal tersebut sejalan dengan pendapat dari Chou bahwa scratchjr merupakan bahasa pemrograman visual yang baru dikembangkan untuk mendorong kompetensi pemikiran komputasional dasar pada anak (Chou, 2020). ScratchJr dapat dideskripsikan sebagai taman bermain online untuk anak usia dini. Seperti taman bermain dalam kehidupan yang nyata, lingkungannya terbuka serta memungkinkan eksplorasi yang ditujukan untuk anak usia dini pada pembuatan proyek yang dapat mengekspresikan minat dan kreativitas untuk anak usia dini. Pengguna scratchJr didorong untuk belajar melalui eksperimen, membuat kesalahan, memperbaiki kesalahan yang telah dibuat, serta dengan melalui proses pemecahan masalah (Sullivan \& Umashi Bers, 2019). 
ScratchJr memiliki palet blok pemrograman, perpustakaan proyek pengguna, editor proyek utama, alat untuk memilih fitur, menggambar karakter, serta grafik latar belakang. Anak usia dini menyeret blok dari palet ke dalam area skrip pembuatan desain serta kemudian menyatukannya untuk membuat suatu program yang dapat dibaca serta dapat dimainkan dari arah kiri menuju ke arah kanan. Blok pemrograman diatur ke dalam enam jenis kategori yang diwakili oleh warna yang beraneka ragam. Blok pemrograman tersebut antara lain adalah : (1) blok pemicu warna kuning; (2) blok motion warna biru; (3) blok tampilan warna ungu; (4) blok suara warna hijau; (5) blok kontrol warna oranye; (6) blok end warna merah. Saat disatukan, blok-blok pemrograman ini memungkinkan anak usia dini untuk mengontrol tindakan karakter yang akan dibuat di layar skrip. Blok pemrograman yang terdapat di dalam scratchjr mencakup konsep dari pengurutan gerakan sederhana sampai struktur kontrol yang lebih kompleks. Desain serta fitur yang terdapat di dalam scratchjr dapat membantu memberikan rangsangan atau mendukung menstimulasi kemampuan pemecahan masalah/ problem solving dengan mengurangi beban kognitif tingkat rendah yang tidak diperlukan. Desain ini menyediakan tantangan pada tingkat tahapan perkembangan yang sesuai serta dapat membantu anak usia dini mencurahkan sumber kognitif serta imajiansinya untuk proses berpikir tingkat tinggi yang berhubungan dengan membayangkan serta membuat program animasi atau cerita interaktif.

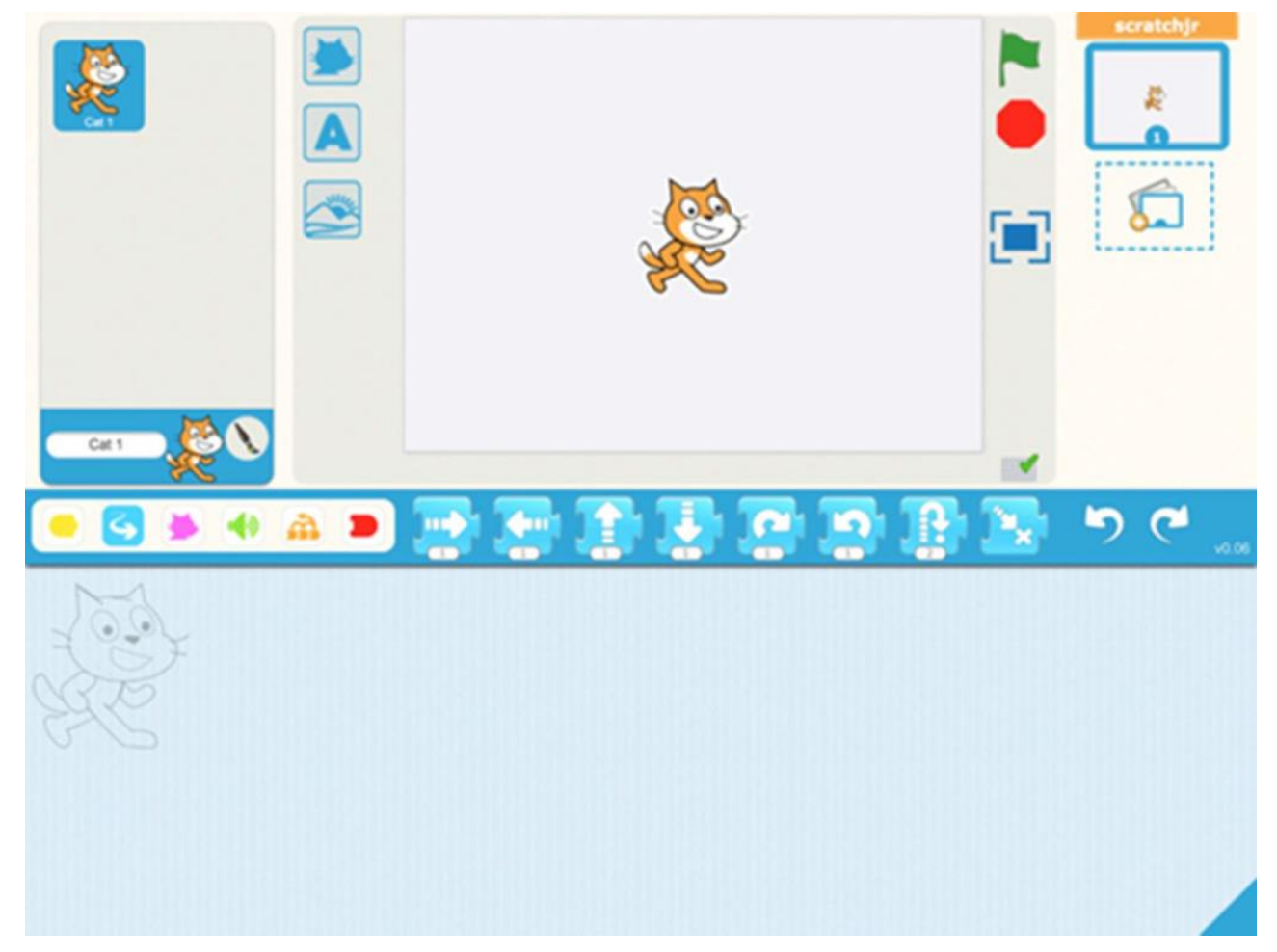

Gambar 1. Tampilan ScratchJr (Portelance et al., 2016)

ScratchJr tersedia secara gratis di berbagai platform tablet, bersama dengan perpustakaan yang kaya akan sumber daya pengajaran dan pembelajaran online untuk digunakan di ruang kelas dan di rumah. Bahasa pengkodean untuk anak usia dini telah mendapatkan popularitas yang cukup besar dalam beberapa tahun terakhir. Sehingga program pendidikan menjadikan ilmu komputer serta literasi teknologi sebagai prioritas untuk anak usia dini. ScratchJr menggunakan bahasa pemrograman untuk membuat dan berbagi game, cerita, video, serta eksplorasi berkode asli lainnya. Penelitian dengan intervensi pemrograman komputer di pusat anak usia dini telah menunjukkan bahwa anak-anak yang berusia lima tahun dapat menguasai konsep pemrograman mendasar dari urutan logis serta 
hubungan sebab dan akibat. ScratchJr dapat menyediakan platform terbuka yang kuat bagi anak usia dini untuk menciptakan eksplorasi pengkodean yang bermakna.

Selain keterampilan pemrograman komputer, scratchJr dirancang untuk mendorong hasil pembelajaran untuk anak usia dini yaitu : (1) pengetahuan khusus domain dalam bidang literasi dan matematika; (2) struktur dasar pengetahuan lintas domain, seperti prediksi dan klasifikasi; (3) keterampilan pemecahan masalah kompleks, termasuk aspek proses desain teknik seperti solusi perencanaan dan pengujian (Strawhacker et al., 2015). Dengan menggabungkan antar muka yang sesuai perkembangan dengan platform pemrograman terbuka yang kuat, scratchJr memungkinkan anak usia dini mencapai tujuan pembelajaran dengan kecepatan mereka sendiri, sebagai bagian dari proses desain dan kreasi mandiri. Karena keefektifan scratchJr bergantung pada cara anak usia dini memahami serta menggunakannya, pengujian dengan guru sangat penting untuk perkembangan anak.

ScratchJr memberikan pembelajaran kemampuan berpikir komputasional untuk membuat cerita dan permainan animasi bagi anak usia dini. Kemampuan berpikir komputasional mencakup pemecahan masalah, pemrosesan informasi, dan desain sistem. Sebuah penelitian telah membuktikan bahwa anak usia empat tahun dapat mempelajari konsep dasar pemikiran komputasional serta pembelajaran kemampuan berpikir komputasional dapat mendukung literasi, matematika, dan perkembangan sosial emosional untuk anak usia dini (Portelance \& Bers, 2015). ScratchJr dirancang untuk memberikan sarana yang sesuai dengan perkembangan anak usia dini untuk mempelajari konsep dan kemampuan pemrograman komputer sembari membuat cerita dan game animasi.

ScratchJr memberikan anak usia dini kesempatan untuk mempelajari seluruh fiturfitur spesifik serta ide-ide atau gagasan-gagasan hebat dari proses pemikiran komputasional seperti debugging serta dekomposisi atau modularitas. Ide-ide atau gagasan-gagasan hebat ini dapat diterapkan secara berguna ke banyak domain di luar konsep ilmu komputer serta teknik seperti ilmu sosial, menulis, serta musik. Dengan menggunakan scratchJr anak usia dini menggunakan blok-blok pemrograman untuk membuat karakter bergerak di sekitar layar skrip serta mengubah penampilan karakter. Anak usia dini juga dapat belajar cara membuat karakter baru dengan cara memilih karakter default dari pustaka karakter scratchjr atau mendesainnya sendiri menggunakan paint editor. Dengan demikian, melalui penggunaan scratchJr maka anak dapat belajar bagaimana memulai skrip terprogram menggunakan fitur bendera hijau dan mewarnai latar belakang kanvas dalam layar skrip.

Scratchjr telah menunjukkan hasil yang positif mengenai pengajaran pemrograman kepada guru pada lembaga pendidikan anak usia dini dengan lingkungan pemrograman (Paper et al., 2017). Belajar membuat kode dan mengembangkan proses pemikiran komputasional adalah kemampuan yang memberikan kontribusi penting bagi proses pembelajaran untuk anak usia dini, membantu anak usia dini menghadapi banyak situasi yang akan mereka temukan dalam hidup, serta memungkinkan anak usia dini untuk berkolaborasi lebih baik antara manusia dan mesin. ScratchJr dapat digunakan untuk membantu guru pada lembaga pendidikan anak usia dini dalam memanfaatkan kemampuan berpikir komputasional serta pemrograman sebagai alat proses kegiatan pembelajaran. ScratchJr berkontribusi dalam menciptakan lingkungan belajar interaktif yang dapat dimanfaatkan oleh anak usia dini.

ScratchJr secara unik berfokus pada kebutuhan perkembangan anak usia 5 hingga 7 tahun, seperti keterampilan motorik halus, kemampuan membaca, serta pengaturan diri. Perangkat lunak dapat berdiri sendiri sebagai alat teknologi, akan tetapi scratchJr telah menciptakan aktivitas pembelajaran yang menyenangkan, menarik, yang melengkapi serta memperkuat perangkat lunak (Flannery et al., 2013). Dengan menggunakan scratchJr, anak usia dini dapat belajar koding dan kemampuan berpikir komputasional dari bahasa komputer, sintaksis, serta latihan akademis menuju koneksi dunis nyata, desain game atau permainan, serta proyek pembangunan. Berdasarkan penelitian menyimpulkan bahwa scratchjr dapat membantu guru dalam memanfaatkan kemampan berpikir komputasional 
serta pemrograman sebagai alat pembeljaran dalam bidang mata pelajaran yang lain seperti matematika dan fisika (Paper et al., 2017).

ScratchJr merupakan lingkungan digital yang kaya media dengan menggunakan struktur perintah blok penyusun untuk memanipulasi aspek grafik, audio, serta video. Penggunaan scratchJr menggabungkan kemampuan berpikir dalam proses pemrograman yang dapat memungkinkan anak usia dini untuk menggabungkan blok-blok bangunan pemrograman serta untuk segera mengamati hasil dari pemrograman tersebut. Blok dapat dipisahkan dan digabungkan kembali saat anak usia dini mengembangkan gerakan serta efek yang diinginkan. ScaratchJr terbukti menjadi ruang yang menarik dan relatif mudah digunakan untuk pemecahan masalah atau problem solving, yang pada saat yang sama menyediakan lingkungan pemrograman yang berharga serta memotivasi untuk mengeksplorasi konsep pemecahan masalah atau problem solving, selain itu terbukti menjadi media yang efektif untuk mendorong komunikasi dan kolaborasi (Calder, 2010).

ScartchJr menciptakan tantangan kegiatan atau permainan untuk anak usia dini secara terang-terangan, sedangkan secara implisit menuntut ide-ide atau gagasan-gagasan untuk mengembangkan permainan yang telah anak usia dini buat programnya. ScratchJr mempunyai blok-blok pengkodean termasuk kontrol logika perulangan, waktu, dan lain sebagainya. Selain itu bahasa pemrograman scratchjr juga memungkinkan musik dan rekaman suara, teks serta gelembung ucapan (Goschnick, 2016). Scartchjr merupakan permainan teknologi digital yang dapat membantu mengembangkan pemikiran kritis dan logis dalam pemecahan masalah (problem solving) dan kompetensi berpikir komputasional.

ScratchJr dikembangkan untuk mendorong anak usia dini untuk terlibat dalam pemikiran berpikir komputasional saat membuat kode (Leidl et al., 2017). Ketika proses berpikir komputasional anak usia ini didukung dengan pembelajaran pengkodean, maka berpotensi untuk melengkapi keterampilan sosial lainnya yang akan bermanfaat untuk anak menjadi ilmuwan komputer di masa depan. ScratchJr menjadi media dimana program dengan mudah disusun serta dimodifikasi, sehingga dapat mendorong penggunaan kemampuan berpikir kritis, meta kognitif, serta reflektif. Scartchjr juga memotivasi secara instrinsik. ScratchJr sebagai media untuk saling membantu secara kolektif untuk memecahkan masalah pemrograman yang sesuai dengan tahap-tahap perkembangan anak.

\section{SIMPULAN}

ScratchJr memungkinkan anak usia dini untuk terlibat dalam pembuatan cerita interaktif, permainan, serta kesenangan digital secara mandiri atau hanya memerlukan sedikit bimbingan di sepanjang jalan proses pembuatannya. Dengan melalui penggunaan scratchjr anak menggunakan konsep geometri serta pengukuran seperti koordinat, pengukuran sudut dan panjang. Selain itu, memfasilitasi pemecahan masalah yang kreatif, penalaran logis, mendukung kolaborasi. Anak usia dini dengan cepat dapat mengakses serta memahami kemampuan pemrograman komputer dengan menggunakan pemikiran matematis dalam pendekatan untuk pemecahan masalah atau problem-solving. Proses yang dilakukan anak usia dini memfasilitasi pemikiran matematis dengan membangkitkan proses pemecahan masalah atau problem-solving yang kreatif serta pengembangan logika dan penalaran saat mereka menanggapi berbagai permasalahan waktu membuat pemrograman.

\section{UCAPAN TERIMA KASIH}

Kami mengucapkan terimakasih kepada Universitas Sebelas Maret yang telah membiayai proses kegiatan penyusunan dan penerbitan artikel ini melalui dana hibah Non Anggaran Pendapatan Belanja Negara Universitas Sebelas Maret (Non-APBN UNS) tahun anggaran 2021 dengan nomor kontrak: 260/UN27.22/HK.07.00/2021 dan kepada semua pihak yang telah membantu dalam menyelesaikan artikel ini. Semoga Allah SWT membalas kebaikan semua pihak. 


\section{DAFTAR PUSTAKA}

Araiza-Alba, P., Keane, T., Chen, W. S., \& Kaufman, J. (2021). Immersive virtual reality as a tool to learn problem-solving skills. Computers and Education, 164(January), 104121. https://doi.org/10.1016/j.compedu.2020.104121

Bers, M. U. (2018a). Coding and Computational Thinking in Early Childhood: The Impact of ScratchJr in Europe. European Journal of STEM Education, 3(3). https:// doi.org/10.20897/ejsteme/3868

Bers, M. U. (2018b). Coding, playgrounds and literacy in early childhood education: The development of KIBO robotics and ScratchJr. IEEE Global Engineering Education Conference, EDUCON, 2018-April, 2094-2102. https:// doi.org/10.1109/EDUCON.2018.8363498

Budak, E. Ç., Geçer, A. K., \& Topal, A. D. (2021). The Effect of Programming with Scratch Course on Reflective Thinking Skills of Students towards Problem Solving. Journal of Learning and Teaching in Digital Age, 6(1), 72-80.

Busch, J. T. A., \& Legare, C. H. (2019). Using data to solve problems: Children reason flexibly in response to different kinds of evidence. Journal of Experimental Child Psychology, 183, 172-188. https://doi.org/10.1016/i.jecp.2019.01.007

Calder, N. (2010). Using Scratch: An integrated problem-solving approach to mathematical thinking. Australian Primary Mathematics Classroom, 15(4), 9-14. http://www.eric.ed.gov/ERICWebPortal/contentdelivery/servlet/ERICServlet?acc no=EJ906680\%5Cnhttp:/ / www.eric.ed.gov/ERICWebPortal/detail?accno=EJ906680

Chou, P. N. (2020). Using ScratchJr to Foster Young Children's Computational Thinking Competence: A Case Study in a Third-Grade Computer Class. Journal of Educational Computing Research, 58(3), 570-595. https://doi.org/10.1177/0735633119872908

Delacruz, S. (2020). Starting From Scratch (Jr.): Integrating Code Literacy in the Primary Grades. Reading Teacher, 73(6), 805-812. https://doi.org/10.1002/trtr.1909

Dyah, A. D. M., \& Setiawati, F. A. (2019). The Problem Solving Skills in Kindergarten Student Based on the Stages of Problem Solving. Jurnal Obsesi : Jurnal Pendidikan Anak Usia Dini, 3(1), 274. https:// doi.org/10.31004/obsesi.v3i1.174

Fessakis, G., Gouli, E., \& Mavroudi, E. (2013). Problem solving by 5-6 years old kindergarten children in a computer programming environment: A case study. Computers and Education, 63, 87-97. https:/ / doi.org/10.1016/j.compedu.2012.11.016

Flannery, L. P., Kazakoff, E. R., Bontá, P., Silverman, B., Bers, M. U., \& Resnick, M. (2013). Designing ScratchJr: Support for early childhood learning through computer programming. ACM International Conference Proceeding Series, 1-10. https:// doi.org/10.1145/2485760.2485785

Goschnick, S. (2016). App Review. International Journal of People-Oriented Programming, 4(1), 50-55. https://doi.org/10.4018/IJPOP.2015010104

Greenwood, C. R., Walker, D., Carta, J. J., \& Higgins, S. K. (2006). Developing a general outcome measure of growth in the cognitive abilities of children 1 to 4 years old: The early problem-solving indicator. School Psychology Review, 35(4), 535-551. https:// doi.org/10.1080/02796015.2006.12087960

Hatzigianni, M. (2018). Transforming early childhood experiences with digital technologies. Global Studies of Childhood, 8(2), 173-183. https:// doi.org/10.1177/2043610617734987

Hufad, A., Faturrohman, M., \& Rusdiyani, I. (2021). Unplugged Coding Activities for Early Childhood Problem-Solving Skills. Jurnal Pendidikan Usia Dini, 15(1), 121-140.

Joseph, G. E., \& Strain, P. S. (2010). Teaching young children interpersonal problem-solving $\begin{array}{llll}\text { skills. Young } & \text { Exceptional }\end{array}$ https:// doi.org/10.1177/1096250610365144 
Kobsiripat, W. (2015). Effects of the Media to Promote the Scratch Programming Capabilities Creativity of Elementary School Students. Procedia - Social and Behavioral Sciences, 174, 227-232. https://doi.org/10.1016/j.sbspro.2015.01.651

Leidl, K. D., Umaschi-Bers, M., \& Mihm, C. (2017). Programming with scratchjr: A review of the first year of user analytics. Proceedings of International Conference on Computational Thinking Education, 116-121.

Lile Diamond, L. (2018). Problem Solving in the Early Years. In Intervention in School and Clinic (Vol. 53, Issue 4, pp. 220-223). https:// doi.org/10.1177/1053451217712957

Nuryatmawati, "Azizah Muthi," \& Dimyati, D. (2021). Efektifitas Pendekatan Saintifik terhadap Kemampuan Pemecahan Masalah Anak Usia 3-6 Tahun. Jurnal Obsesi : Jurnal Pendidikan Anak Usia Dini, 5(2), 2071-2081. https://doi.org/10.31004/obsesi.v5i2.1048

Palmer, S. B., Summers, J. A., Brotherson, M. J., Erwin, E. J., Maude, S. P., Stroup-Rentier, V., wu, H. yi, Peck, N. F., Zheng, Y., Weigel, C. J., Chu, S. Y., Mcgrath, G. S., \& Haines, S. J. (2013). Foundations for Self-Determination in Early Childhood: An Inclusive Model for Children With Disabilities. Topics in Early Childhood Special Education, 33(1), 3847. https:// doi.org/10.1177/0271121412445288

Papadakis, S., Kalogiannakis, M., \& Zaranis, N. (2016). Developing fundamental programming concepts and computational thinking with ScratchJr in preschool education: A case study. International Journal of Mobile Learning and Organisation, 10(3), 187-202. https://doi.org/10.1504/IJMLO.2016.077867

Paper, C., Kalogiannakis, M., ... S. P. the 12th C. of the, \& 2017, U. (2017). A proposal for teaching ScratchJr programming environment in preservice kindergarten teachers. Academia.Edu, October, 2013-2015. https://www.researchgate.net/publication/320546761

Popay, J., Roberts, H., Sowden, A., Petticrew, M., Arai, L., Rodgers, M., Britten, N., Roen, K., \& Duffy, S. (2006). Guidance on the Conduct of Narrative Synthesis in Systematic Reviews A Product from the ESRC Methods Programme Peninsula Medical School, Universities of Exeter and Plymouth. April 2006, 1-92. https://citeseerx.ist.psu.edu/viewdoc/download?doi=10.1.1.178.3100\&rep=rep1\&ty pe $=$ pdf

Portelance, D. J., \& Bers, M. U. (2015). Code and tell: Assessing young children's learning of computational thinking using peer video interviews with ScratchJr. Proceedings of IDC 2015: The 14th International Conference on Interaction Design and Children, 271-274. https://doi.org/10.1145/2771839.2771894

Portelance, D. J., Strawhacker, A. L., \& Bers, M. U. (2016). Constructing the ScratchJr programming language in the early childhood classroom. International Journal of Technology and Design Education, 26(4), 489-504. https://doi.org/10.1007/s10798$\underline{015-9325-0}$

Razban, S., Shahhosseyni, S., \& Bagheri, M. (2020). The Effect of Programming Training via Scratch Software on Student Problem Solving Skill. Evaluasi Publikasi Pendidikan Akademik, 3, 93-107.

Rose, S. P., Jacob Habgood, M. P., \& Jay, T. (2017). An exploration of the role of visual programming tools in the development of young children's computational thinking. $\begin{array}{llll}\text { Electronic Journal of 297-309. } & \text { E-Learning, 15(4), }\end{array}$ https:// doi.org/10.34190/ejel.15.4.2368

Setyaningtyas, P., \& Harun, H. (2020). Brain Based Learning Efektif Meningkatkan Kemampuan Pemecahan Masalah Konsep Bilangan Anak Usia Dini. Jurnal Obsesi : Jurnal Pendidikan Anak Usia 1021. https://doi.org/10.31004/obsesi.v4i2.479 
Strawhacker, A., Lee, M., Bers, M., \& Caine, C. (2015). ScratchJr Demo: A coding language for Kindergarten. Proceedings of IDC 2015: The 14th International Conference on Interaction Design and Children, 414-417. https://doi.org/10.1145/2771839.2771867

Strawhacker, A., Lee, M., \& Bers, M. U. (2018). Teaching tools, teachers' rules: exploring the impact of teaching styles on young children's programming knowledge in ScratchJr. International Journal of Technology and Design Education, 28(2), 347-376. https:// doi.org/10.1007/s10798-017-9400-9

Sullivan, A., \& Umashi Bers, M. (2019). Computer Science Education in Early Childhood: The Case of ScratchJr. Journal of Information Technology Education: Innovations in Practice, 18, 113-138. https:// doi.org/10.28945/4437

Unahalekhaka, A., \& Bers, M. U. (2021). Taking coding home: analysis of ScratchJr usage in home and school settings. Educational Technology Research and Development, 69(3), 1579-1598. https://doi.org/10.1007/s11423-021-10011-w

Yalçın, V., \& Erden, Ş. (2021). The Effect of STEM Activities Prepared According to the Design Thinking Model on Preschool Children's Creativity and Problem-Solving Skills. Thinking Skills and Creativity, 41(May). https://doi.org/10.1016/j.tsc.2021.100864

Yu, K. C., Fan, S. C., \& Lin, K. Y. (2015). Enhancing Students' Problem-Solving Skills Through Context-Based Learning. International Journal of Science and Mathematics Education, 13(6), 1377-1401. https://doi.org/10.1007/s10763-014-9567-4 
Lampiran 1

Tabel 2 Hasil Temuan Studi Dampak Aplikasi ScratchJr terhadap Ketrampilan Problem-Solving Anak Usia Dini

\begin{tabular}{|c|c|c|}
\hline Kategori & Pustaka & Temuan \\
\hline \multirow{8}{*}{$\begin{array}{l}\text { Dampak } \\
\text { ScratchJr } \\
\text { Terhadap } \\
\text { Ketrampilan } \\
\text { Problem } \\
\text { Solving Anak } \\
\text { Usia Dini }\end{array}$} & $\begin{array}{c}\text { (Yalçın \& } \\
\text { Erden, 2021) }\end{array}$ & $\begin{array}{l}\text { Kegiatan membuat proyek dapat berkontribbusi pada } \\
\text { perkembangan anak untuk memahami masalah, membuat } \\
\text { kesimpulan logis, interpretasi masalah yang berbeda, } \\
\text { meningkatkan ketrampilan problem-solving, komunikasi, dan } \\
\text { kolaborasi }\end{array}$ \\
\hline & $\begin{array}{c}\text { (Kobsiripat, } \\
\text { 2015) }\end{array}$ & $\begin{array}{l}\text { Mengarahkan pengembangan kreativitas melalui kegiatan } \\
\text { pembelajaran yang inovatif dan mempromosikan proses } \\
\text { berpikir tingkat tinggi (Higher Order Thinking) untuk } \\
\text { memecahkan masalah agar anak dapat kritis memikirkan solusi }\end{array}$ \\
\hline & $\begin{array}{l}\text { (Portelance \& } \\
\text { Bers, 2015) }\end{array}$ & $\begin{array}{l}\text { Melibatkan anak membuat animasi cerita interaktif untuk } \\
\text { mengeksplorasi konsep pemrograman kompleks melalui proses } \\
\text { problem-solving menemukan solusi }\end{array}$ \\
\hline & (Calder, 2010) & $\begin{array}{l}\text { ScratchJr terintegrasi pada proses ketrampilan problem-solving } \\
\text { yang otentik, kreatif, penalaran logis, berpikir rasional, } \\
\text { mendorong kolaborasi, menggunakan logika dan penalaran } \\
\text { untuk mengevaluasi dan menafsirkan situasi dalam proses } \\
\text { investigasi }\end{array}$ \\
\hline & $\begin{array}{l}\text { (Goschnick, } \\
\text { 2016) }\end{array}$ & $\begin{array}{l}\text { ScratchJr memungkinkan anak usia dini untuk terlibat dalam } \\
\text { pembuatan cerita interaktif, permainan, dan mengasah problem- } \\
\text { solving secara mandiri }\end{array}$ \\
\hline & $\begin{array}{l}\text { (Papadakis et } \\
\text { al., 2016) }\end{array}$ & $\begin{array}{l}\text { Scratchjr dapat mengembangkan ketrampilan problem-solving } \\
\text { dengan cara yang menyenangkan dan ideal untuk } \\
\text { pengembangan ketrampilan menulis, membaca, dan } \\
\text { matematika sesuai perkembangan anak usia dini }\end{array}$ \\
\hline & (Bers, 2018a) & $\begin{array}{l}\text { Scratchir adalah taman bermain pengkodean digital yang dapat } \\
\text { mengembangkan strategi problem-solving dengan menggunakan } \\
\text { penalaran heuristik untuk menemukan banyak kemungkinan } \\
\text { solusi, memperbaiki masalah secara sistematis melalui analisis } \\
\text { dan evaluasi untuk melakukan suatu pekerjaan dengan benar }\end{array}$ \\
\hline & $\begin{array}{l}\text { (Hufad et al., } \\
\text { 2021) }\end{array}$ & $\begin{array}{l}\text { Permainan pengkodean dapat mengembangkan ketrampilan } \\
\text { problem-solving, melihat peristiwa dengan perspektif orang lain, } \\
\text { serta merumuskan langkah-langkah untuk menemukan solusi } \\
\text { dari masalah yang dihadapi anak }\end{array}$ \\
\hline
\end{tabular}

Konsep pemrograman komputer sederhana dapat memperkuat

(Portelance et ketrampilan kognitif seperti kemampuan matematika, literasi,

al., 2016) kreativitas, berpikir divergen, melatih berpikir kritis yang lebih efektif, dan ketrampilan problem-solving untuk menyusun strategi pemecahan masalah pada anak usia dini

Dampak Anak usia dini dapat secara bebas terlibat untuk

ScratchJr (Unahalekhaka mengeksplorasi scratchjr secara kreatif dan bebas bermain

Terhadap \& Bers, 2021) tanpa adanya batasan waktu tertentu untuk membangun

Ketrampilan penguasaan dengan balok-balok scratchjr dasar

Problem

Solving Anak

Usia Dini

Scratchjr dapat mengembangkan sikap keberanian dan kepercayaan diri untuk mengambil resiko, toleransi untuk membuat kesalahan, dan problem-solving untuk mencapai tujuan

(Strawhacker solusi pemrograman menyelesaikan satu urutan atau hasil dan et al., 2018) mengoreksi serta mengidenifikasi program yang ada dalam scratchjr berdasarkan pengamatan anak untuk belajar dari kesalahan 


\begin{tabular}{ccl}
\hline Kategori & Pustaka & \multicolumn{1}{c}{ Temuan } \\
\hline (Budak et al., & $\begin{array}{l}\text { Proses problem-solving yang memungkinkan peningkatan } \\
\text { pengalaman belajar dengan mempertahankan minat anak } \\
\text { melalui cara memahami masalah, menganalisis masalah, } \\
\text { mengembangkan solusi, menerapkan cara penyelesaian dengan } \\
\text { pengkodean dan evaluasi }\end{array}$ \\
\cline { 2 - 3 } (Fessakis et al., & $\begin{array}{l}\text { Pendekatan problem-solving untuk menggunakan metode coba- } \\
\text { coba mengikuti langkah demi langkah yang memungkinkan } \\
\text { rencana pengembangan solusi pada masalah yang dihadapi }\end{array}$ \\
\hline & $\begin{array}{l}\text { Pendekatan problem-solving untuk pemrograman meliputi } \\
\text { pendekatan analisis top down dimana solusi untuk masalah } \\
\text { direncanakan dan pendekatan bottom up atau bricolage dimana } \\
\text { (Rose et al., } \\
\text { 2017) } \\
\text { bernegosiasi untuk mendapatkan solusi terbaik }\end{array}$ \\
\cline { 2 - 3 } (Razban et al., & $\begin{array}{l}\text { Pemrograman dengan scratch berpengaruh signifikan terhadap } \\
\text { pengetahuan ketrampilan problem-solving dengan menganalisis } \\
\text { masalah dan mencoba berbagai tantangan mendapatkan solusi } \\
\text { untuk menyelesaikan masalah }\end{array}$ \\
\hline
\end{tabular}

